\title{
A REVIEW OF CONSTRAINT FACTORS IN COMPLYING WITH BUILDING CONTROL REGULATION RELATED TO HOUSE RENOVATION
}

\author{
Putri Nabila Kamarulzaman*1, Nur Farhana Azmi², Raha Sulaiman² \\ ${ }^{1}$ Department of Building Surveying, University of Malaya, 50603 Kuala Lumpur, Malaysia \\ ${ }^{2}$ Center for Building, Construction and Tropical Architecture (BuCTA), Department of Building Surveying, \\ Faculty of Built Environment, University of Malaya, 50603 Kuala Lumpur, Malaysia
}

E-mail: *bgc170004@siswa.um.edu.my, farhanazmi@um.edu.my, rahasulaiman@um.edu.my

\begin{abstract}
The purpose of the study is to provide a review on the constraint factors in complying with building control regulation related to house renovation. Adapting the qualitative approach, an extensive review was made on the existing literature related to the constraint factors to comply with building control regulation and guidelines with regards to house renovation. The study found that the constraint factors can be classified into four main categories based on the perspective of four key stakeholders' groups in renovation works; law and policy maker, local authority, the professionals, and homeowners. The complexity of existing building legislation and guideline has been identified as the most fundamental issue that contributes to non-compliant renovation works in Malaysia. The paper concludes with the recommendation that the current legislations and guidelines pertaining to house renovation in the country need to be reviewed considering the interest of stakeholders. This study is deemed to be one of many researches that contribute to the existing gap in literature on building control with regards to existing buildings.
\end{abstract}

Keywords : Building control, compliance, house renovation, terrace houses, regulation

\section{INTRODUCTION}

There are various types of residential properties in Malaysia, from bungalows and terrace houses to apartments and condominiums. In Malaysian market, landed houses such as detached, semi-detached and terrace houses still remain as the most preferred type of residential property among the public. Even though high-density and high-rise types of residential property such as low-cost flat, apartment and condominium are more popularly found in urban areas in Malaysia, potential homebuyers still prefer landed housing over high-rise ones despite facing affordability issues (Im \& Fah, 2018; Ling, Mansur, \& Musthafa, 2016) .

Alongside the strong market of landed property, there is also a growing trend of building renovation, especially among terrace houses. The habit of renovating houses had caused uncontrolled and chaotic environment among local houses. Hence enhancing compliance among renovated houses is a challenge in achieving sustainable communities in the country (Sabri, Ujang, Arif, \& Aripin, 2018). Extreme renovation and extension have become commonplace due to the escalating price of houses which resulted in poor compliance has become a common phenomenon (Loong, 2016; Sabri, Ujang, Arif, \& Aripin, 2017; Saji, 2012). Saji (2012) stated a concern over excessive renovation being a common view in Malaysian context, and how the issue is not being addressed appropriately by the respective local authorities. According to Sabri et al. (2018), there have been many cases of poor compliance involving constructions which have been conducted in violation of the approved plan. The researcher also mentioned that four local authorities in Selangor recorded that 40-60\% of house owners who had their house renovations approved had deviated from the approved plans. Besides that, during year 2016, from the total of house owners who applied for Certificate of Completion and Compliance (CCC) to Selayang Municipal Council (MPS) and Subang Jaya Municipal Council (MPSJ), only 10\% of them claimed their deposits once the 
renovation completed (Sabri et al., 2018). Being only 10\% who claimed, the remaining $90 \%$ might has deviated from the approved plan, or only use the building approval to get the work started.

According to Chayes, Chayes, and Mitchell (1998), non-compliance may also reflect negligence and the inability to understand the provision of law. In spite of building control for new developments has predominated the literature, minimal work has been dedicated to the control of existing buildings (Yau \& Chiu, 2015). Therefore, this study aims to evaluate the constraint factors in complying with the building control regulations related to house renovations.

\subsection{Constraint factors in complying to building control regulation related to house renovation}

Retrieved from the limited amount of studies made on illegal or non-compliant building renovation, several constraint factors have been discovered (Alnsour \& Meaton, 2009; Maidin, Kadouf, \& Sulaiman, 2012; Sabri et al., 2017, 2018; Sarkheyli, Sharifi, Rafieian, Bemanian, \& Murayama, 2012) and categorised into perspective from four different groups. The groups are created based on the main players involved in making house renovations legal, which are the law and policy maker, local authority, the professionals and homeowners. Referring to Figure 1, through the top-down approach, the whole process of house renovations starts with a set of law that allow, control and empower the local authority to govern every affair of its area. Each local authority will then have its own procedure and guideline when it comes to house renovations. Different local authority has different approach in dealing with illegal renovations. Next, the professionals act as the vital bridge to connect the public with the laws and regulations. Professionals are those who conduct the construction work, submission of plans and directly advise their clients pertaining to the renovation matters. Lastly, the homeowners are the final player, the one who actually decides whether to abide or infringe the law with regards to house renovation.

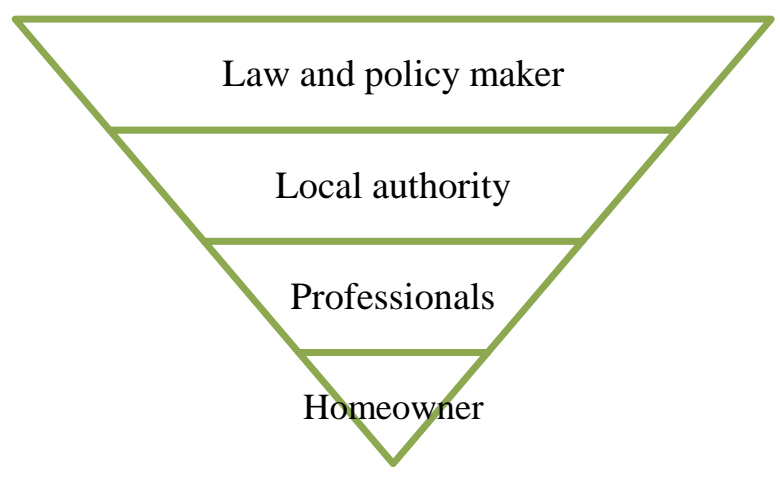

Figure 1: Key players with regard to house renovations

Source: Adapted from Alnsour and Meaton (2009), Maidin et al. (2012), Sabri et al. (2017),

Sabri et al. (2018), and Sarkheyli et al. (2012)

\subsection{Law and policy maker}

Government is the first main contributor in ensuring legality in building renovation, as it act as both the lawmaker and the key player in ensuring a law is enforced accordingly. Maidin et al. (2012) explained that the strength of the rule of law is the best indicator of a country's success, in which good governance should promote accountability, transparency, efficiency and rule of law in public institutions at all fields. Maidin et al. (2012) also elaborated on the consequences of not having good governance (through improper functioning institutions), nonobservance of the rule of law is that it will impede social stability and cause legal certainty.

According to Maidin et al. (2012), there are several factors influencing implementation and enforcement of law. First is the lack of political will. A law could never be fully effective if there is no political power behind it to ensure sufficient amount of resources and energy is put to its implementation. The second factor is the failure to foresee methods and costs of an effective implementation of law. In the context of building renovations, such failure could cause problems within the local authority's level such as shortage of skilled officer for residential 
property inspections, delay in processing penalty or demolition for illegal renovation works and delay in building approval processes. Financial problem caused by the government in implementing the law is supported by Alnsour and Meaton (2009) who argued that the lack of financing (government inability to provide finance facilities) has a significant impact on the extent of compliance in regards to the residential standards. The third factor is the lack of understanding of the law by regulators and the failure to engage the civil society in the law-making process.

There is a need to put collaborative efforts from all stakeholders and lawmakers cannot rely entirely on review of written instruments or through legal experts only. The lack of understanding causes legal gaps to occur in planning regulations, giving rooms for the municipal staff to utilize to maintain kinship ties and personal interest (Alnsour \& Meaton, 2009). Other than that, the public is also not adequately educated on the nature of law once it's made. As a result, the government fails to build up support from the stakeholders who are the most likely to be affected such as contractors and architects, causing resistance from stakeholders in implementing the law. They may remain ignorant in complying to the law or understand the benefits of the law.

\subsection{Local authority}

Section 8 of Local Government Act 1976 (Act 171) empowers the local authority to administer every affair in its area. Section 102 of the Act further empowers local authority to establish, amend and revoke by-laws in all matters as deemed necessary from time to time. Every local authority has their own procedure and guideline with regards to house renovation. There are several challenges and issues encountered pertaining to illegal building renovation and the local authority including organisation's priority, ineffective building monitoring system, lack of skilled officer and the complex processes of obtaining planning approvals.

Merton (1940) in Rooij (2006) mentioned that an organization might prioritize contextual goal rather than primary goal, which is compliance. There are certain local authorities who place high priority in the collection of the revenue instead of preventing illegal renovation works and ensuring building compliance in terrace houses (Sabri et al., 2017). Sarkheyli et al. (2012); Zegarac (1999) supported this statement by expressing that local authorities tend to make legal penalty as a source of revenue. Sabri et al. (2017) further explained that collection of revenue is the main factor in measuring performance which causes achievement based on job efficiency and rate of compliance are being neglected. Furthermore, local authority often put priority in increasing the penalty and the assessment rate, reflecting how revenue-driven local authorities are with regards to building renovation. Loh (2015) reported that approximately 3000 households in Taman Cempaka and Desa Cempaka were unhappy with the increase between $10 \%$ and $276 \%$ in their assessment rates. Besides imposing penalties, there are other option in dealing with illegal building renovation, one of which is demolition. Sabri et al. (2017) mentioned that demolition was agreed to have a better impact in educating the public to comply. However, the lengthy and complicated process has resulted in the works being completed, making it more difficult to be demolished. Zegarac (1999) supported by stating that delayed demolition of illegally constructed houses are one of the reasons for the ongoing illegal construction. Sabri et al. (2017) also stated that court orders and prosecution are also found to be effective in handling illegal building renovations, but the process is time-consuming and requires a copious amount of documentations.

Besides, approval process is also one of the main factors why homeowners and the professionals refuse to conduct building renovation legally. Loong (2016) stated that a lot of people has disregarded the rules whilst the enforcement was lax. Many has opined that local authority's approval process is rather difficult, expensive and time consuming (Ali \& Zakaria, 2012; Loh, 2015; Sarkheyli et al., 2012; Zegarac, 1999). Other than that, another issue that has surfaced in local authority's context is lack of building monitoring. Sabri et al. (2017) stated that most authorities target to conduct regular visits to the respective residential area at least twice a month, but results showed that the target was never achieved. Kuala Lumpur City Hall which is also known as DBKL on the other hand, only detects illegal renovations from the lodged public complaints. This is merely because they lack manpower to conduct a regular building monitoring. The ineffectiveness of building monitoring causes the capacity to detect illegal and non-compliant renovation work unattainable (Alnsour \& Meaton, 2009; Sabri et al., 2017). It is mostly because lack of financial aid from the government and lack of competent staff to carry out such jobs (Alnsour \& Meaton, 2009; Rukwaro, 2009; Sabri et al., 2017; Sarkheyli et al., 2012). 


\subsection{Professionals}

Cooperation from the professionals such as contractor and architect is vital in order to encourage the public to exercise the correct building renovation practice. The professionals act as a bridge between existing laws and guidelines and the public. Maidin et al. (2012) stated that resistance from the professionals in implementing the law could occur if the public is not adequately educated about the nature of law once made. They also may remain ignorant of how to comply or to take advantage of the law over other people (Maidin et al., 2012). Besides, there are contractors and architects that prefer not to submit plans for approval as it is expected to demand a lot of time, effort and resources (Loh, 2015; Sabri et al., 2017). House owners could be heavily influenced by the contractor and consultant as the professionals are the one who have been entrusted by their clients and their advices to the house owners could be misleading and lead to poor compliance to the regulation. Sabri et al. (2018) discovered through interviews with house owners that contractors and consultants who are trusted by them offered misleading advices which leads to poor compliance to the regulation. There are several contractors who insist to continue their illegal renovations despite the sites being sealed and warning letters issued to them by the local authority. It shows that the legislation and guidelines pertaining to house renovations are not being taken seriously by the public which leads to such infringement to become a norm.

\subsection{Homeowner}

Homeowners are the last main player for this building renovation cycle process. They would be the one that can demand their building renovation work to be in accordance to the stipulated law and regulation. The best policy can be created but will still be neglected if there is no cooperation from the community. The most mentioned issue that surfaced among homeowners is awareness (Alnsour \& Meaton, 2009; Rukwaro, 2009; Sarkheyli et al., 2012). However, Sabri et al. (2018) argued that awareness is not the main problem because house owners are mostly aware that they have to abide by the regulations when it comes to house renovations. The researcher stated that there are other external factors that made house owners break the law despite being aware about the regulations.

These factors include legal capacity, social constraint and financial constraint. Regarding legal capacity, there are house owners who find the legal procedure to renovate a house is hard and confusing (Sabri et al., 2018). Through the researcher's findings, there are house owners who would want to abide the law but find it hard to do so. In their opinion, the legislation and guideline books are too thick, and the terms used are hard for them to understand. There are also negative perceptions towards legal procedure, especially the approval process (Sabri et al., 2018). Secondly, a social constraint is where the house owners are indirectly influenced by the neighbors' actions in illegally renovating their houses. There are situations where the visual influence of neighbors' renovated houses was carried out without abiding to the setback regulation influenced the house owner's decision to infringe the law. Besides, Rukwaro (2009) mentioned that $84 \%$ of the respondents in his research believe that they have the right to renovate their space. This is supported through interviews made with the house owners. It is found that due to limited availability of land, house owners expressed their rights to do whatever they want within the boundary of their land (Sabri et al., 2018). Lastly, for financial constraint, house owners prefer to renovate mainly because they could not afford to buy a new house within the area they desire. Kuala Lumpur City Hall (KLCH) stated in their house renovation guidelines that the steep price in property market makes it harder for homeowners to purchase larger houses (DBKL, 2017). Besides, there are house owners who admitted that they could not abide the law because the approval process by the local authority is rather expensive and time consuming (Sabri et al., 2018). They also have concern over the price they have to pay if they resubmit the plans to the local authority.

\section{METHODOLOGY}

For this study, a qualitative approach is used where extensive review was made on the existing literature related to constraint factors in complying with building control regulations pertaining to house renovation. As it is in the initial stage, it is anticipated in the future that the compliance constraint factors with regard to house renovation and its existing regulations and guidelines to be asked through questionnaire survey and interview sessions with the homeowners and the key stakeholders respectively. 


\section{RESULTS \& DISCUSSION}

The study generates understanding on the constraint factors in complying with the building control regulation related to house renovation. Figure 2 summarises the findings obtained from the review on the factors of compliance constraint. It is found that there is minimal collaborative effort between the policy makers and the practicing professionals when it comes to the creation of law and policy, which causes the failure to foresee an effective law implementation. Besides, there is also an issue on the local authority's goal in enforcing the law, which was argued where local authorities often prioritise collection of revenue rather than ensuring compliance when it comes to house renovations. There is also negative perception from the public towards local authority especially its legal procedure for house renovation where it is deemed to be complicated, expensive and time consuming. For the homeowners, they find that the legal procedures regarding house renovation is hard for them to follow. They also claimed that the guidelines provided are rather too thick to read and difficult to understand.

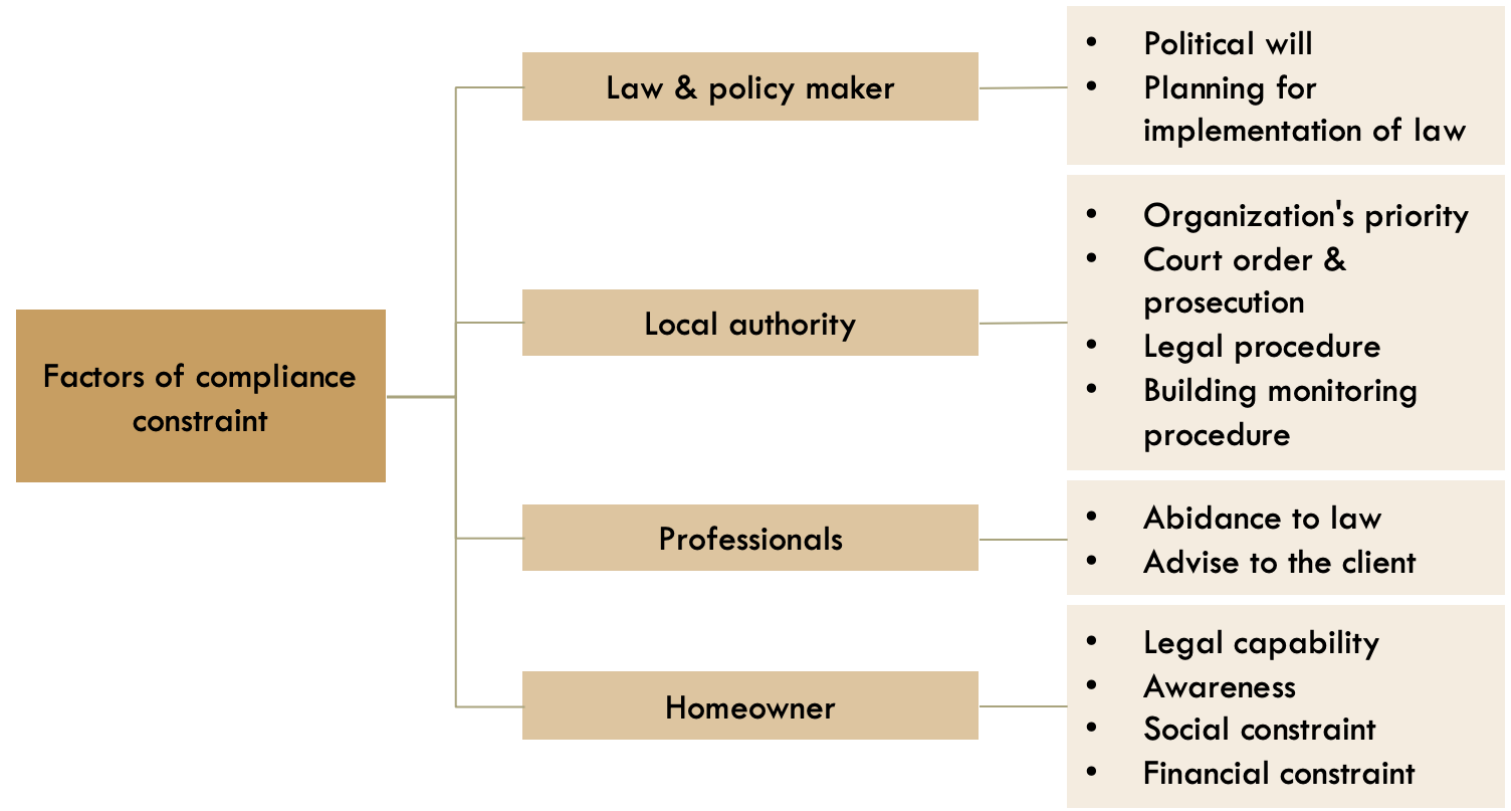

Figure 2: Factors of compliance constraint

Source: Author

\section{CONCLUSION}

Based on the issues discovered, it is found that legislations and guidelines pertaining to house renovation in the country need to be reviewed considering interests of stakeholders. It is vital to acknowledge that every stakeholder plays important role in ensuring renovation practice is in the right track. This study is deemed to be one of many researches that contributes to the existing gap with the literature on building control with regards to existing buildings.

\section{ACKNOWLEDGMENTS}

The authors gratefully acknowledge the financial support of the Fundamental Research Grant Scheme (FRGS), grant no FP027-2017A established by the Ministry of Education Malaysia (MoHE). 


\section{REFERENCES}

Ali, A. S., \& Zakaria, R. (2012). Complexity of statutory requirements: Case study of refurbishment projects in Malaysia. Journal of Building Performance, 3(1).

Alnsour, J., \& Meaton, J. (2009). Factors affecting compliance with residential standards in the city of Old Salt, Jordan. Habitat International, 33(4), 301-309. doi:10.1016/j.habitatint.2008.08.003

Chayes, A., Chayes, A. H., \& Mitchell, R. B. (1998). Managing compliance: A comparative perspective. In E. B. Weiss \& H. Jacobson (Eds.), Engaging countries: Strengthening compliance with international environmental accords (pp. 39-62): MIT Press, Cambridge.

Garis panduan ubahsuai rumah kediaman jenis teres/ berangkai 1, 2 dan 3 tingkat lot saiz biasa (standard lot) di Wilayah Persekutuan Kuala Lumpur, (2017).

Im, L. P., \& Fah, C. Y. (2018). Preferences of residential typologies of urban malaysians. Journal of the Malaysian Institute of Planners, 16(3), 171-181.

Ling, O., Mansur, N. A., \& Musthafa, S. N. (2016). The housing preference of young people in Malaysian urban areas: A case study of Subang Jaya, Selangor. Malaysian Journal of Society and Space, 12(7), 60-74.

Local Government Act 1976. (2006). The Comissioner of Law Revision, Malaysia.

Loh, I. (2015). Home renovations that break the rules - Metro News. The Star Online. Retrieved from https://www.thestar.com.my/metro/community/2015/07/07/home-renovations-that-break-the-rulesproperty-owners-try-to-save-time-and-money-by-not-informing-lo/

Loong, C. K. (2016). Making it legal - Business News The Star Online. Retrieved from https://www.thestar.com.my/business/business-news/2016/12/03/making-it-legal/

Maidin, A. J., Kadouf, H. A., \& Sulaiman, S. S. (2012). The Role of Law in Fostering Sustainability in the Built Environment Industry: The Malaysian Experience. Australian Journal of Basic and Applied Science, 6(11), 90-96.

Rukwaro, R. W. (2009). The owner occupier democracy and violation of building by-laws. Habitat International, 33(4), 485-498. doi:10.1016/j.habitatint.2009.03.004

Sabri, B. K. M., Ujang, N., Arif, A. M. M., \& Aripin, S. (2017). Measures in curbing poor compliance to building control regulation among renovated terrace houses. International Journal of Law in the Built Environment, 9(3), 256-271. doi:10.1108/ijlbe-06-2017-0018

Sabri, B. K. M., Ujang, N., Arif, A. M. M., \& Aripin, S. (2018). Compliance constraints among house owners of renovated terrace and semi-detached houses in Selangor, Malaysia. Journal of Humanities, Language, Culture and Business, 2(10), 37-44.

Saji, N. (2012). A Review of Malaysian Terraced House Design and the Tendency of Changing. Journal of Sustainable Development, 5(5). doi:10.5539/jsd.v5n5p140

Sarkheyli, E., Sharifi, A., Rafieian, M., Bemanian, M. R., \& Murayama, A. (2012). An investigation of the reasons for non-compliance with FAR regulations in Tehran. Cities, 29(4), 223-233. doi:10.1016/j.cities.2011.09.004

Yau, Y., \& Chiu, S. M. (2015). Combating building illegality in Hong Kong: A policy Delphi study. Habitat International, 49, 349-356. doi:10.1016/j.habitatint.2015.06.006

Zegarac, Z. (1999). Illegal construction in Belgrade and prospects for urban development planning. Cities, 16(5), 365-370. 